\title{
APLIKASI E-VOTING UNTUK PEMILIHAN KEPALA DESA BERBASIS WEBSITE
}

\author{
Abdul Azis ${ }^{1)}$, Ito Setiawan ${ }^{2)}$, Arif Risqiantoro ${ }^{3)}$ \\ 1,2) Sistem Informasi STMIK AMIKOM Purwokerto \\ ${ }^{3)}$ Teknik Informatika STMIK AMIKOM Purwokerto \\ email :abdazis9@amikompurwokerto.ac.id ${ }^{1)}$,itosetiawan@amikompurwokerto.ac.id ${ }^{2)}$,arifrisqiantoro@gmail.com ${ }^{3)}$
}

\begin{abstract}
Abstraksi
Negara Indonesia adalah negara yang menganut sistem demokrasi. Dimana setiap warganya berhak memilih pemimpin melalui pemilihan umum. Di Desa Tayem Timur pemilihan kepala desa memiliki beberapa seperti partisipasi pemilih yang rendah, resiko terjadinya kecurangan pemungutan suara, suara tidak sah dan tingginya biaya pelaksanaan pilkades. Kendala tersebut dapat diatasi dengan memanfaatkan teknologi aplikasi berbasis web. Aplikasi dibuat dengan menggunakan framework CodeIgniter dengan membangun fitur input data daftar pemilih tetap, data calon kepala desa, pencetakan kartu pemilih, pemungutan suara dan rekapitulasi hasil pemungutan suara. Metode penelitian yang digunakan adalah Prototipe dengan tahapan mendengarkan pelanggan, membangun, memperbaiki prototipe dan menguji prototipe. Pengujian menggunakan metode black box testing untuk menguji fungsionalitas sistem. Hasil dari penelitian ini adalah Aplikasi Pemilihan Kepala Desa Berbasis Web untuk Desa Tayem Timur.
\end{abstract}

Kata Kunci :

Pilkades, Web, 5E-Voting

\section{Pendahuluan}

Negara Indonesia adalah negara yang menganut sistem demokrasi dimana semua warga negaranya memiliki hak yang sama dalam pengambilan keputusan yang dapat merubah hidup mereka. Salah satu implementasi dari sistem demokrasi yaitu diselenggarakannya pemilihan umum mulai dari tingkat desa hingga pemilihan presiden dan wakil presiden. Menurut peraturan Bupati Cilacap nomor 156 tahun 2018 tentang tata cara penyaluran, penggunaan, dan pelaporan bantuan keuangan kepada pemerintah desa untuk biaya pemilihan kepala desa serentak di Kabupaten Cilacap pada bab I pasal 1 nomor 5 disebutkan,desa adalah kesatuan masyarakat hukum yang memiliki batas wilayah yang berwenang untuk mengatur dan mengurus urusan pemerintahan, kepentingan masyarakat setempat berdasarkan prakarsa masyarakat, hak asal-usul, dan/atau hak tradisional yang diakui dan dihormati dalam sistem pemerintahan Negara Kesatuan Republik Indonesia. Pada bab I pasal 1 nomor 13 disebutkan, pemilihan kepala desa adalah pelaksanaan kedaulatan rakyat di desa dalam rangka memilih kepala desa yang bersifat langsung, umum, bebas, rahasia, jujur dan adil.

Desa Tayem Timur merupakan sebuah desa yang terletak di kecamatan Karangpucung kabupaten Cilacap dengan luas 1.156,04 hektar. Desa Tayem Timur memiliki wilayah geografis berupa pegunungan, hutan pinus, kebun dan permukiman penduduk yang tidak terlalu padat. Jumlah penduduk desa Tayem Timur adalah sebanyak 7.021 jiwa dan rata - rata masyarakatnya berprofesi sebagai petani 2213 orang, pedagang 339 orang dan sebagian kecil

pegawai swasta dan pegawai negeri sipil (Buku monografi desa keadaan desember 2016).

Pada Pemilihan Kepala Desa (Pilkades) di Desa Tayem Timur, sistem yang berjalan menggunakan sistem pencoblosan. Awal dari kegiatan pemilihan adalah pembentukan Panitia Pemilihan yang dilaksanakan oleh Badan Permusyawaratan Desa (BPD) dan dihadiri oleh masyarakat, Pemerintah Desa, Lembaga Kemasyarakatan Desa, tokoh masyarakat dan unsur Musyawarah Pimpinan Kecamatan(Muspika) setempat dan ditetapkan 4 bulan sebelum berakhir masa jabatan kepala desa. Panitia Pemilihan tersebut anggotanya terdiri dari unsur perangkat desa, pengurus lembaga kemasyarakatan dan tokoh masyarakat yang berjumlah 11 orang terdiri dari ketua, wakil ketua, sekretaris bendahara dan anggota. Setelah itu panitia melakukan pengumuman akan diadakannya pemilihan Kepala desa kemudian selanjutnya melakukan pendaftaran pemilih tetap.

Kegiatan selanjutnya adalah melaksanakan penjaringan dan penyaringan bakal calon Kepala Desa. Kemudian menyiapkan undangan sesuai dengan daftar pemilih yang telah ditetapkandan dibagikan oleh ketua RT kepada warga setempat. Panitia kemudian melakukan pelaksanaan pemungutan suara dan perhitungan suara pada waktu dan tempat yang telah ditetapkan. Pelaksanaan pemungutan suara dimulai pada pukul 7.00 dan berakhir pada pukul 13.00 waktu setempat. Pemberian suara untuk pemilihan dilakukan dengan mencoblos pada salah satu tanda gambar dalam surat suara. Setelah kegiatan pemungutan suara maka dilaksanakan kegiatan perhitungan suara yang dilakukan oleh Panitia Pemilihan dan disaksikan oleh calon kepala desa dan saksi calon serta Panitia 
Pengawas, kemudian Panitia Pemilihan menetapkan hasil perhitungan suara yang didapat pada saat kegiatan perhitungan suara. Dalam pelaksanaan Pilkades tersebut, $\mathrm{t}$ erdapat beberapa masalah yang timbul diantaranya adalah tingginya persentase sebanyak 35,5\%pemilih yang tidak dapat hadir dikarenakan bekerja di luar kota.Dari data rekapitulasi suara pada Pilkades desa Tayem Timur 26 November 2018,dari sebanyak 5007 Daftar Pemilih Tetap (DPT) yang terdaftar, hanya 3230 orang yang hadir ke Tempat Pemungutan Suara (TPS).

Ada pula beberapa masalah yang terjadi pada kegiatan pemilihan tersebut yakni terdapat beberapa surat suara yang tidak sah yaitu sejumlah 13 suara dantingginya biaya operasional yang mencapai 74 juta rupiah untuk menyelenggarakan kegiatan pemilihan kepala desa tersebut, biaya operasional tersebut meliputi administrasi (pengumuman, pembuatan dan pengiriman undangan, pembuatan kotak suara, pembuatan tanda atau surat suara, formulir pendaftaran, pembuatan surat keputusan, pelaporan dan sebagainya), pendaftaran pemilih, pembuatan bilik atau kamar tempat pemilihan,penelitian syarat-syarat calon, honorarium panitia dan petugas pemilihan Kepala Desa dan pembentukan dan pelaksanaan kegiatan Panitia Pengawas.Anggota Panitia Pilkades Tayem Timur Edi Mustofa menyebutkan seluruh biaya penyelenggaraan kegiatan pemilihan kepala desa tersebut masuk kedalam anggaran APBDesa.

Terdapat pula masalah lain dari sistem perhitungan suara dengan sistem manual yaitu resiko kesalahan perhitungan suara dan kecurangan mengenai jumlah suara. Drehem, dkk (2016) menyebutkan bahwa pelaksanaan pemungutan suara secara manual memiliki kelemahan antara lain yaitu tingginya risiko kesalahan penghitungan suara mengingat banyaknya jumlah surat suara yang harus dihitung dan rawan terjadi kecurangan terhadap jumlah suara untuk kepentingan partai atau golongan tertentu. Kelemahan tersebut mengakibatkan kualitas pelaksanaan pemilu dan kepercayaan rakyat terhadap hasil pemilu menurun. Pada Pilkada Kabupaten Pekalongan dan Kebumen Tahun 2015, terdapat kejadian berupa pelanggaran yakni pemilih yang memilih lebih dari satu kali atau lebih yang mengakibatkan dilaksanakannya Pemungutan Suara Ulang (PSU) (Perdana, 2018).

Dalam hal ini, pemanfaatan perkembangan teknologi informasi dapat dilakukan untuk mengatasi masalah tersebut. Untuk dapat mengatasi masalah tersebut, maka diperlukan sebuah sistem Pemilihan Kepala Desayang memudahkan pemilih dalam menggunakan haknya dan meminimalisir biaya dalam penyelenggaraannya serta tetap menganut asas Pemilihan Umum (Pemilu) yaitu langsung, umum, bebas, rahasia, jujur dan adil.

Salah satu teknologi informasi yang dapat dimanfaatkan untuk sistem pemilihan tersebut adalah aplikasi berbasis web.Aplikasi berbasis web adalahaplikasi yang tidak harus diinstalldahulu dikomputer atau aplikasi yang bisa langsungdijalankan denganmenggunakan web browser.Aplikasi berbasis web memiliki keunggulan yaitu ringan dan dapat diakses dengan cepat melalui browser dan koneksi internet ke server. Ini berarti bahwa pengguna dapat mengakses informasi dengan mudah melalui laptop, smartphone, bahkan komputer PC tanpa harus menginstal aplikasi yang diperlukan hanya untuk mengakses data/informasi. (Junanda dkk, 2016).

Tujuan dari penelitian ini adalah menghasilkan sebuah Aplikasi Pemilihan Kepala Desa Berbasis Web sebagai solusi untuk sistem Pemilihan Kepala Desa Tayem Timuryang efektif menambah partisipasi pemilih dengan memudahkan pemilih menggunakan hak pilihnya, menghilangkan suara tidak sah, menanggulangi resiko kecurangan dan serta dapat menekan biaya penyelenggaraan kegiatan Pilkades.

\section{Tinjauan Pustaka}

A. Kepala Desa

Kepala Desa adalah pemimpin dari desa di Indonesia. Kepala Desa merupakan pimpinan dari pemerintah desa. Masa jabatan Kepala Desa adalah 5 (lima) tahun, dan dapat diperpanjang lagi untuk satu kali masa jabatan berikutnya.

\section{B. Kode QR (Quick Response Code)}

Quick Response Codeatau yang biasa disebut dengan $Q R$ Code merupakan sebuah barcode dua dimensi yang diperkenalkan oleh perusahaan Jepang yaitu Denso Wave pada tahun 1994. Jenis barcode ini awalnya digunakan untuk pendataan inventaris produksi suku cadang kendaraan dan sekarang sudah digunakan dalam berbagai bidang layanan bisnis dan jasa untuk aktifitas marketing dan promosi. Menurut Rouillard (2008) dalam Tedy, pada dasarnya bahwa QR Codedikembangkan sebagai suatu kode yang memungkinkan isinya untuk dapat diterjemahkan dengan kecepatan tinggi. Oleh karena itu, $Q R$ Codedapat menampung informasi yang lebih banyak dibandingkan dengan barcode satu dimensi (Tedy, 2013).

C. Framework CodeIgniter

CodeIgniter (CI) adalah sebuah framework yang digunakan untuk membuat sebuah aplikasi berbasis web yang disusun menggunakan bahasa PHP. Didalam CI ini terdapat berberapa macam kelas yang terbentuk library dan helper yang berfungsi untuk membantu pemrogram dalam mengembangkan aplikasinya. CI sangat mudah dipelajari oleh seorang pemrogram web pemula sekalipun. Alasannya karena CI mempunyai file dokumentasi yang sangat memadai untuk menjelaskan setiap fungsi yang ada pada library dan helper. File dokumentasi ini disertakan secara langsung pada saat anda mengunduh paket 
framework CI. Seperti halnya PHP, CI juga bersifat free opensource software dimana setiap orang berhak menggunakan tanpa harus dikenai biaya lisensi (Riyanto, 2011). CI (CodeIgniter) dapat digunakan dengan menggunakan server webApache dan MS ISS. Hanya saja tidak semua fitur CI dapat di implementasikan dengan sempurna di MS ISS, karena CI dirancang dan di kembangkan dengan acuan Apache (Sidik, 2012).

\section{Metode Penelitian}

A. Metode Pengumpulan Data

\section{Observasi}

Menurut Sugiono (2012) menyatakan, observasi sebagai teknik pengumpulan data yang mempunyai ciri spesifik berkenaan dengan perilaku manusia, proses kerja, gejala - gejala alam, dan responden yang diamati tidak terlalu besar. Dari segi proses pelaksanaan pengumpulan data, observasi dapat dibedakan menjadi participant observation dan non participant observation (Sugiono, 2018).

2. Wawancara

Sugiono (2012) mengemukakan bahwa, wawancara adalah percakapan dengan maksud tertentu, percakapan itu dilakukan oleh dua belah pihak, yaitu pewawancara (interviewer) yang mengajukan pertanyaan dan terwawancara (interviewe) yang memberikan jawaban atas pertanyaan itu.

\section{Studi Pustaka}

Menurut Sugiono dalam Nugroho (2017), studi kepustakaan merupakan studi yang berkaitan dengan kajian teroritis dan referensi lain yang berkaitan dengan penelitian, selain itu studi kepustakaan sangat penting dalam melaksanakan penelitian, hal ini dikarenakan penelitian tidak lepas dari literatur - literatur ilmiah.

4. Angket atau Kuesioner

Menurut Sugiono (2012), kuesioner merupakan teknik pengumpulan data yang dilakukan dengan cara memberi seperangkat pertanyaan atau pernyataan tertulis kepada responden untuk dijawabnya

\section{B. Tahap Penelitian}

Tahapan penelitian yaitu tahapan yang akan dilakukan peneliti untuk mempermudah dalam melakukan penelitian. Desain penelitian digambarkan pada gambar berikut.:

Metode Pengumpulan Data :
Observasi
Wawancara
Kuesioner
Studi Pustaka

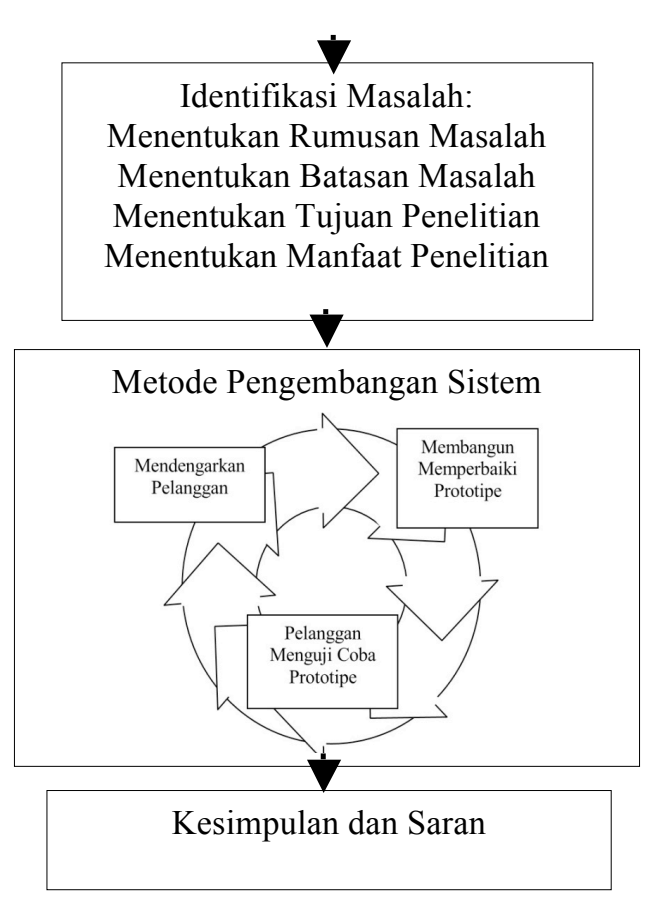

Gambar 1. Tahap Penelitian

\section{Hasil dan Pembahasan}

Dalam penelitian ini, model pengembangan sistem yang digunakan adalah model prototipe. Dalam model ini pengembang dan pelanggan saling bekerja sama dalam memberikan arahan dan masukan untuk keberhasilan sebuah sistem. Seperti yang telah dijelaskan bahwa metode prototipe ini memiliki tiga tahapan yaitu mendengarkan pelanggan, membangun/memperbaiki prototipe, dan pengujian program prototype.

A. Mendengarkan pelanggan

Pada tahap ini peneliti melakukan observasi pada kegiatan Pilkades Desa Tayem Timur untuk mengetahui dan mendapatkan gambaran mengenai sistem yang akan dibuat menjadi fitur - fitur dan objek program. Tahap selanjutnya peneliti melakukan kegiatan wawancara kepada Bapak Edi Mustofa yang menjabat sebagai Sekretaris Desa. Pada kegiatan wawancara tersebut, peneliti mengajukan sebuah rancangan awal program dan pihak desa memberi masukan terhadap program tersebut sesuai dengan keadaan dan kebutuhan. Dalam hasil kegiatan observasi dan wawancara tersebut maka telah diketahui kebutuhan sistem yang akan dibangun yaitu halaman untuk pemilih dan admin.

1. Kebutuhan Fungsional Halaman Admin

Pada halaman admin, fungsi yang dapat digunakan yaitu mengelola data calon pemilih, mencetak kartu pemilih, mengelola data calon Kepala Desa, mengatur waktu jadwal pemungutan suara, mengelola hasil pemungutan suara. Untuk dapat mengakses semua fungsi tersebut, maka harus melewati halaman login terlebih dahulu. Untuk deskripsi masing - masing halaman akan di jelaskan sebagai berikut : 
a) Halaman Login

Pada perancangan halaman login, seorang admin diharuskan memasukan username dan password kemudian menekan tombol login. Jika kombinasi username dan password benar maka akan menampilkan halaman Berandaatau Homeadmin. Kemudian jika kombinasi tersebut salah maka akan menampilkan pesan bahwa username atau password salah.

b) Halaman Home

Pada perancangan halaman Beranda atau Home, seorang admin dapat melihat jumlah daftar pemilih dan total suara yang telah masuk, serta dapat melihat statistik presentase awal suara yang telah masuk kepada masing masing calon kandidat kepala desa.

c) Halaman Data Pemilih

Pada perancangan halaman data pemilih, admin dapat melakukan proses kegiatan tambah data calon pemilih dengan memasukan data identitas dari pemilih tersebut seperti nomor kepala keluarga, nama kepala keluarga, nama pemilih, tempat dan tanggal lahir serta alamat. Kemudian pada halaman ini admin dapat melakukan perubahan data dan hapus data apa bila diperlukan serta dapat melihat status dari pemilih tersebut apakah telah melakukan pemungutan suara atau belum.

d) Halaman Data Calon

Pada perancangan halaman data pemilih, admin dapat melakukan proses input data berupa nama nama calon kandidat Pilkades yang akan dipilih oleh calon pemilih. Data tersebut merupakan foto calon, nama calon, serta visi dan misi calon tersebut, nantinya data tersebut akan ditampilkan pada halaman pemungutan suara

e) Halaman Data Jadwal

Pada halaman data jadwal, rancangannya ialah admin dapat melakukan penentuan dan perubahan jadwal kapan kegiatan pelaksanaan pemungutan suara akan dimulai. Sehingga pengaturan jadwal tersebut berpengaruh pada halaman pemungutan suara hanya dapat diakses ketika dalam rentang waktu jadwal yang telah ditentukan tersebut.

f) Halaman Data Real Count

Pada rancangan halaman data real count, admin dapat menginformasikan halaman ini hasil dari proses pemungutan suara setelah kegiatan seluruh proses tersebut berakhir. Pada halaman ini terdapat presentase total suara yang masuk dan total jumlah suara serta total jumlah suara setiap kandidat.

2. Kebutuhan Fungsional Halaman Pemilih

a) Halaman Scan QR Code

Pada rancangan halaman QR Code ini, pemilih dapat menscan QR Code yang terdapat pada kartu pemilih untuk masuk pada halaman pemilihan kandidat. Ketika QR Code tersebut belum pernah digunakan sebelumnya, maka pada saat scan berhasil langsung akan ditujukan menuju halaman pemilihan kandidat / halaman vote. Tetapi ketika QR Code tersebut telah digunakan maka pada saat scan akan ditampilkan keterangan QR Code salah, karena QR Code tersebut hanya dapat digunakan satu kali dalam proses pemungutan suara.

b) Halaman Vote

Pada rancangan halaman vote, pemilih akan ditampilkan gambar berupa foto calon calon kandidat kepala desa beserta misi dan visinya dan melakukan proses vote / memilih dengan cara menyentuh salah satu gambar foto calon kepala desa tersebut dan halaman tersebut akan otomatis beralih ke halaman scan kembali ketika pemilih telah menyentuh salah satu gambar kandidat tersebut

\section{B. Membangun/Memperbaiki Prototipe}

Setelah kegiatan analisis kebutuhan fungsional dan non fungsional, maka telah disimpulkan gambaran program yang akan dibuat. Untuk tahap selanjutnya yaitu adalah tahap membangun / memperbaiki prototipe. Tahapan yang dilakukan tersebut adalah sebagai berikut :

1. Desain Arsitektur Sistem

a) Unified Modeling Language

1) Definisi Aktor

Aktor disini merupakan orang yang berinteraksi atau menggunakan aplikasi. Pada aplikasi ini yang menjadi aktor adalah Admin dan User (pemilih). Berikut adalah pendefinisian aktor pada aplikasi ini :

Tabel 1. Definisi Aktor

\begin{tabular}{|l|c|l|}
\hline No. & Aktor & \multicolumn{1}{|c|}{ Deskripsi } \\
\hline 1. & Admin & $\begin{array}{l}\text { Orang yang bertugas dan } \\
\text { memiliki hak akses mengelola } \\
\text { data pemilih, data calon, data } \\
\text { jadwal, serta data jumlah suara } \\
\text { dan juga pencetakan kartu } \\
\text { pemilih. }\end{array}$ \\
\hline 2. & User & $\begin{array}{l}\text { Orang yang melakukan fungsi } \\
\text { sebagai pemilih (voter) dalam } \\
\text { aplikasi ini. }\end{array}$ \\
\hline
\end{tabular}

Berikutnya pendefinisian use case pada aplikasi ini akan dijelaskan pada tabel berikut :

Tabel 2. Definisi Use Case

\begin{tabular}{|l|l|l|}
\hline No & Case Use & \multicolumn{1}{|c|}{ Deskripsi } \\
\hline 1. & Login & $\begin{array}{l}\text { Proses melakukan login } \\
\text { untuk masuk kedalam } \\
\text { sistem. }\end{array}$ \\
\hline 2. & $\begin{array}{l}\text { Mengakses } \\
\text { Menu Data } \\
\text { Pemilih }\end{array}$ & $\begin{array}{l}\text { Admin dapat melakukan } \\
\text { proses kelola data pemilih } \\
\text { meliputi daftar pemilih, } \\
\text { hapus pemilih, rubah data } \\
\text { pemilih, dan cetak kartu } \\
\text { pemilih. }\end{array}$ \\
\hline 3 & $\begin{array}{l}\text { Mengakses } \\
\text { Menu Data } \\
\text { Calon }\end{array}$ & $\begin{array}{l}\text { Admin dapat melakukan } \\
\text { proses kelola data calon } \\
\text { meliputi daftar calon, }\end{array}$ \\
\hline
\end{tabular}




\begin{tabular}{|l|l|l|}
\hline & & \multicolumn{2}{|l|}{$\begin{array}{l}\text { rubah data calon dan hapus } \\
\text { data calon. }\end{array}$} \\
\hline 4 & $\begin{array}{l}\text { Mengakses } \\
\text { Menu Data } \\
\text { Jadwal }\end{array}$ & $\begin{array}{l}\text { Admin dapat melakukan } \\
\text { proses kelola jadwal } \\
\text { pemilihan dimulai dan } \\
\text { selesai. }\end{array}$ \\
\hline 5 & $\begin{array}{l}\text { Mengakses } \\
\text { Menu Data } \\
\text { Real Count }\end{array}$ & $\begin{array}{l}\text { Admin dapat melihat data } \\
\text { hasil perhitungan } \\
\text { pemungutan suara. }\end{array}$ \\
\hline 6 & $\begin{array}{l}\text { Logout } \\
\text { Proses untuk keluar dari } \\
\text { sistem. }\end{array}$ \\
\hline 7 & $\begin{array}{l}\text { Mengakses } \\
\text { itur pilih } \\
\text { calon }\end{array}$ & $\begin{array}{l}\text { User dapat melakukan } \\
\text { proses pemilihan } \\
\text { calon/kandidat yang } \\
\text { terdaftar. }\end{array}$ \\
\hline
\end{tabular}

2. Use Case Diagram

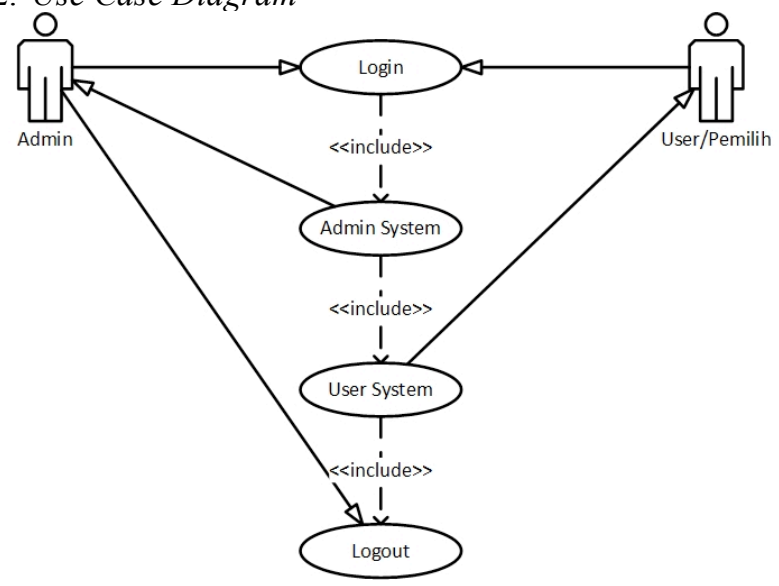

Gambar 2. Use Case Diagram Index

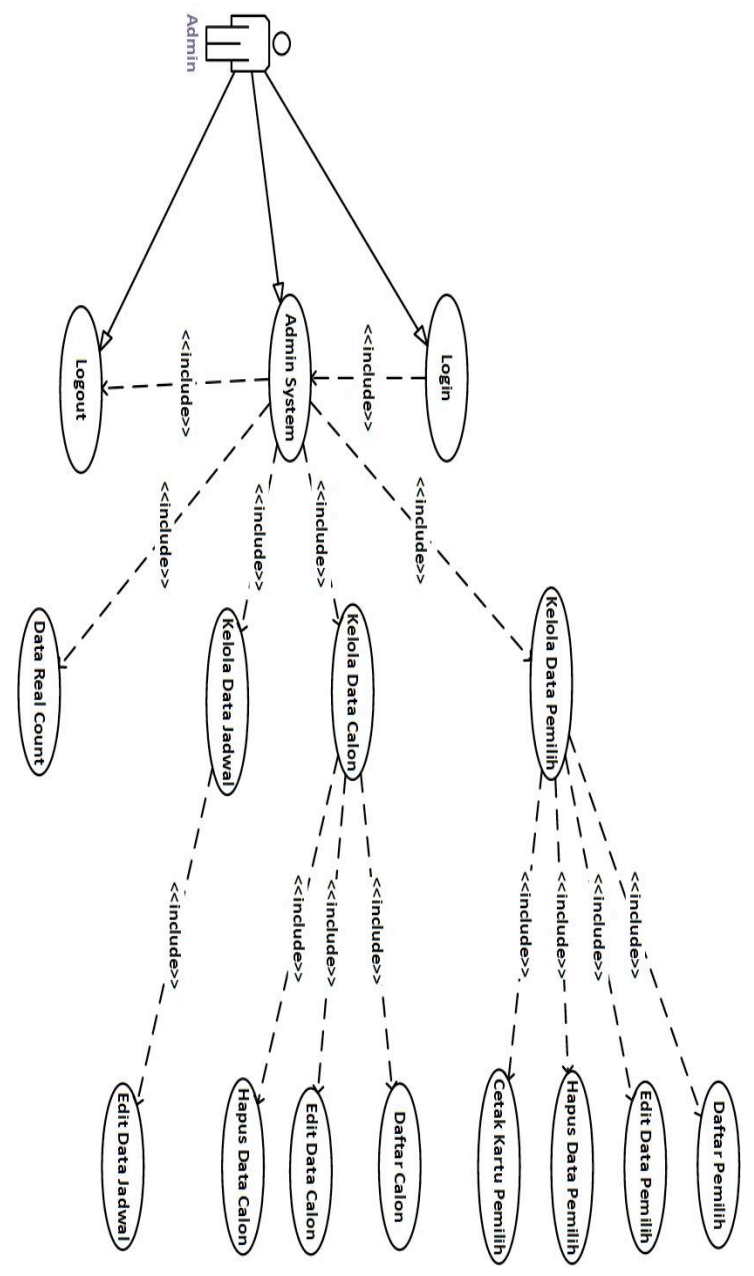

Gambar 3. Use Case Diagram Admin

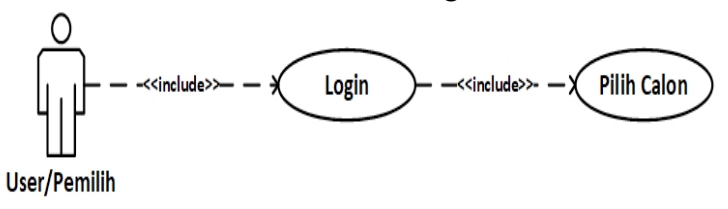

Gambar 4 Use Case Diagram User (Pemilih).

3. Activity Diagram

Activity Diagram digunakan untuk menggambarkan aliran kerja atau proses dari sebuah sistem atau proses bisnis atau menu yang ada diperangkat lunak. Berikut merupakan activity diagram dari sistem Aplikasi Pemilihan Kepala Desa Berbasis $W e b$ : 


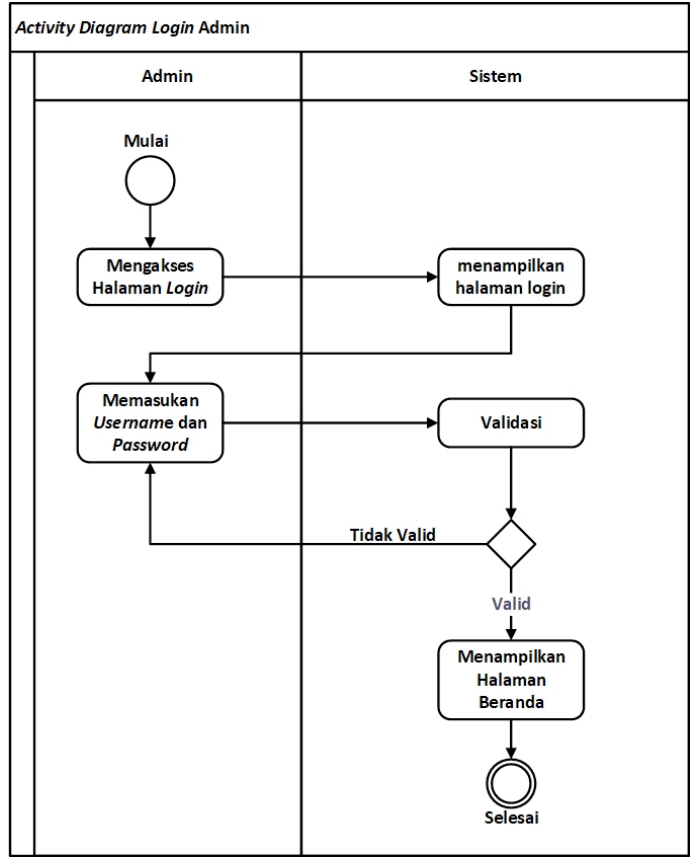

Gambar 5. Activity Diagram Login Admin

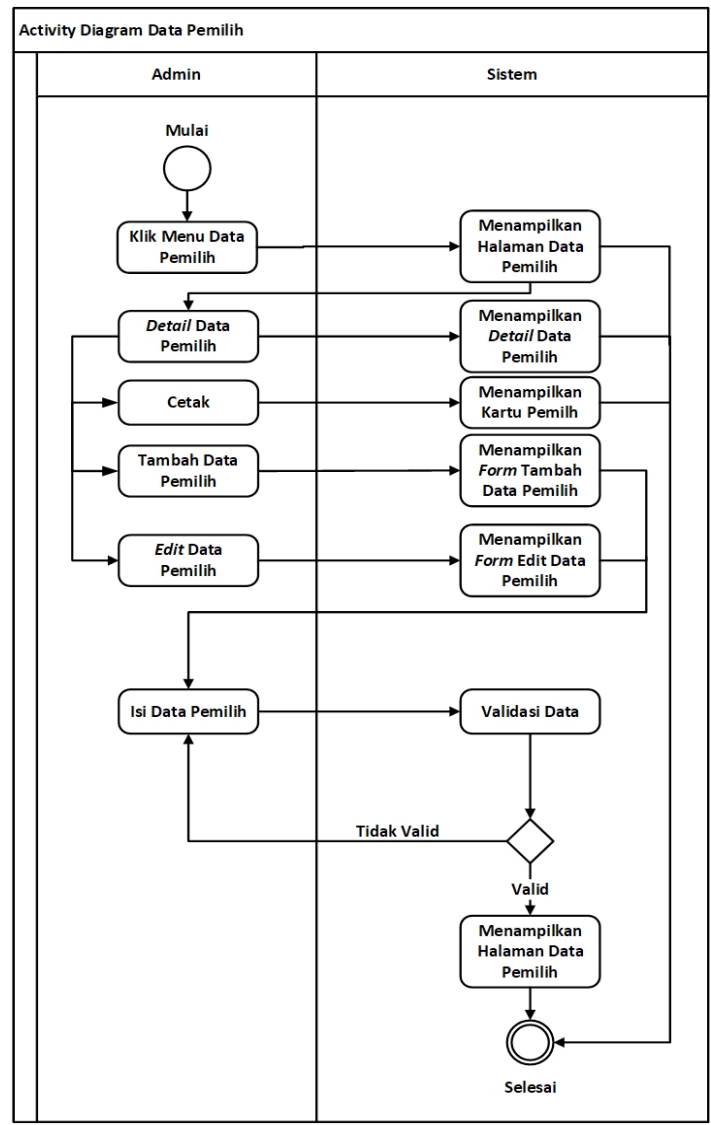

Gambar 5. Activity DiagramData Pemilih

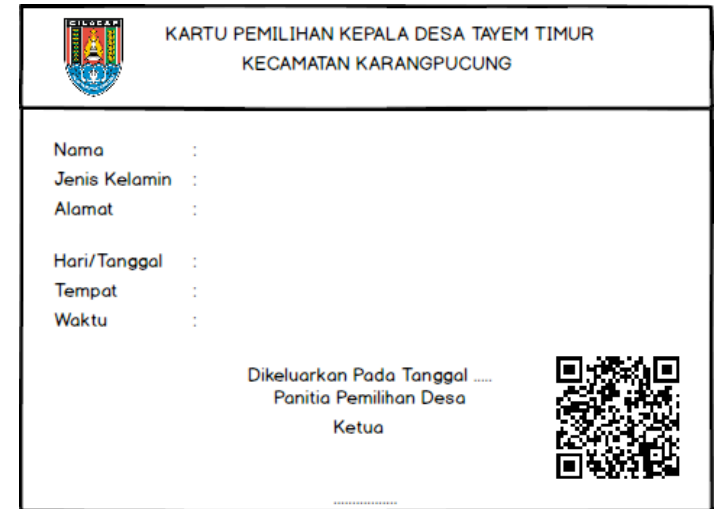

Gambar 6. Desain Kartu Pemilih

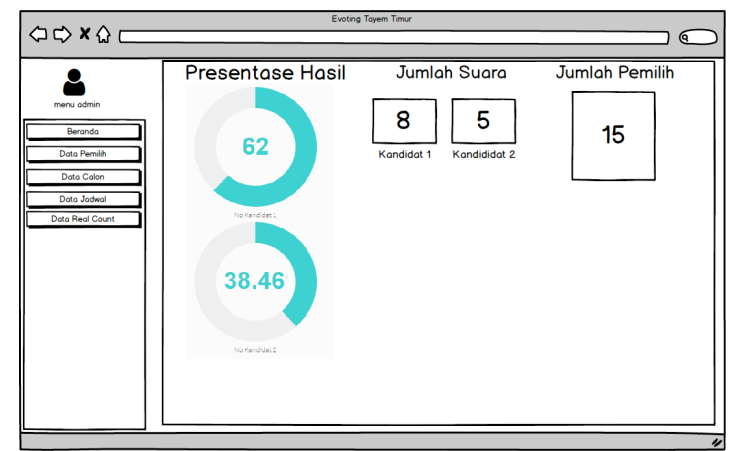

Gambar 7. Antarmuka Halaman Real Count

\section{Kesimpulan dan Saran}

A. Kesimpulan

Berdasarkan pembahasan dan uraian hasil penelitian pada bab - bab sebelumnya, maka dapat diambil berberapa kesimpulan sebagai berikut :

1. Penelitian ini telah berhasil membangun Aplikasi Pemilihan Kepala Desa Berbasis $W e b$ di Desa Tayem Timur.

2. Berdasarkan User Acceptance TestingAplikasi Pemilihan Kepala Desa Berbasis Web ini telah sesuai dengan perancangan yang telah ditetapkan pada tahap desain sistem serta sesuai dengan keinginan pelanggan (Panitia Pemilihan Kepala Desa Tayem Timur).

B. Saran

Dari semua hasil yang telah dicapai saat ini, saran untuk aplikasi pemilihan kepala desa berbasis web ini adalah :

1. Aplikasi ini perlu dikembangkan dalam segi desain antarmuka agar lebih menarik dan interaktif.

2. Aplikasi ini belum menerapkan sistem keamanan terenkripsi untuk menjamin keamanan dari tindak peretasan data 


\section{Daftar Pustaka}

[1] Abdurahman, H., Riswaya, AR. "Aplikasi Peminjaman Pembayaran Secara Kredit Pada Bank Yudha Bhakti." Jurnal Computech \& Bisnis, 8(2),61-69, 2014.

[2] Afriliani, S., Fitrani, A,S. "Sistem Aplikasi Pemilihan Kepala Desa Berbasis Web (Studi Kasus Desa Sumengko Kabupaten Nganjuk)." Jurnal Teknik Informatika Universitas Muhammadiyah Sidoarjo, 2015.

[3] Aji, S., Pinilih, M,. Hermanto, N. "Aplikasi EVoting Pemilihan Kepala Desa Berbasis Web di Desa Timbang." Jurnal Publikasi Teknik Informatika STMIK Amikom Purwokerto, 2017.

[4] Anugerah, I,. Widianti, U.D. "Pembangunan Sistem Informasi Supply Chain Management Di Cv. Cihanjuang Inti Teknik Divisi Minuman Tradisional." Jurnal Teknik Informatika Universitas Komputer Indonesia, 2017.

[5] Ariska, Jery., Jazman, M. "Rancang Bangun Sistem Informasi Manajemen Aset Sekolah Menggunakan Teknik Labeling QR Code (Studi Kasus : MAN 2 Model Pekanbaru)." Jurnal Rekayasa dan Manajemen Sistem Informasi, 2 Agustus 2016.

[6] Budiaji, W. "Skala Pengukuran Dan Jumlah Respon Skala Linkert." Jurnal Ilmu Pertanian dan Perikanan Universitas Sultan Ageng Tirtayasa, Desember 2013.

[7] Desa Tayem Timur, "Buku Monografi Desa Keadaan.”, Desember 2016.

[8] Dewi, NS., "Efektivitas Sistem Electronic VotingDalam Pemilihan Kepala Desa Di DesaPa'jukukang Kecamatan Pa'jukukang Kabupaten Bantaeng." Program Studi Administrasi Negara Jurusan Ilmu Administrasi Fakultas Ilmu Sosial Dan Ilmu Politik Universitas Hasanuddin, 2016. 